\title{
Study on the Development of County Finance in Shaanxi Province
}

\author{
Liu Kairui, Li Zhe \\ International Business School of Shaanxi Normal University, China \\ snnulizhe@snnu.edu.cn
}

Keywords: county finance; county economy; Shaanxi Province; empirical analysis

\begin{abstract}
County economy is an important part of the national economy. The county financial development has important practical significance to the regional economic and social development. Shaanxi Province is located in the northwestern part of China, being in a certain gap compared with the developed areas. At the same time, as the starting point of the ancient Silk Road, Shaanxi Province needs a good foundation and support of county financial development in order to do a good job to catch the important strategic opportunity of the "One Belt and One Road" plan. This paper selects three of the ten strongest counties in Shaanxi Province of Gaoling County in Xi'an City, Jingbian County in Yulin City, and Zhidan County in Yan'an City, through the analysis of financial data and other indicators, to study the county financial development status of Shaanxi Province, and to put forward the relevant policy recommendations.
\end{abstract}

\section{Research Significance}

Shaanxi Province is located in the northwestern part of China, with a certain lag in the field of financial development compared with the developed areas. There are still many contradictions and discordance. The continued role of county finance to the comprehensive development of county is weakening, and even it can not fully meet the needs of the county economy, thus restrains the county's development. Shaanxi Province is one of the provinces on the plan of "One Belt and One Road", and the county financial system of rich construction feature, diverse forms, and in line with local conditions is of great strategic significance to fully integrate regional resources, to enhance the strength of regional economy, to create regional economic development platform, and to build a new economic starting point of silk path with efforts in Shaanxi Province.

\section{A Summary of County Financial Development Researche}

There have been a lot of researches on county finance and many research results have been obtained. Chen Chun (2009) put forward the problems and causes of county financial institutions in the service of county economy, and gave the policy recommendations from aspects of the external environment of rural financial development, the recreation of rural financial system, the strengthening of the prevention to rural financial institutions and control of rural financial risks and so on. Shi Quanhu (2009) suggested that raising capital required for the development of county economy, adjusting industrial structure of county economy, and driving flow of other production factors are manifestations of the important support role of county financial development to the county economic growth. Wang Minhui (2010) analyzed the county economy and county financial development status in Shaanxi Province based on the definition of county economy, revealed the problems such as the shortage of financial supply and capital outflow in the financial support of the county economy in Shaanxi Province, and then further made empirical research from the perspective of taking Heyang County in Shaanxi and the entire Shaanxi Province as an example, on the endogenous economic growth model to the financial support of the county economic growth, thus proved the existence of financial repression in county economic development of Shaanxi. 


\section{Financial Development Theory}

Since the mid twentieth Century, the theory of economic growth and financial development has been studied more in-depth, including the theory of financial repression and financial deepening put forward by the economist R.I. Mackinnon and E.S. Shaw, which dialectically expounded the relationship between financial development and economic growth in developing countries. Financial repression means that the development of economic system is lagging behind because of the intervention from the government and other public sectors, and it ultimately leads to a vicious cycle of financial repression and economic development blocked. Financial deepening theory refers to the government and other public sectors to give up too much intervention on financial markets and the financial system, with the main performance in the control of interest rates and exchange rate, to give full play to the market and reflect the relation of supply and demand, thus contribute to increase savings and investment, and actively allocate financial resources for the economy booming, to further expand the demand for the financial industry, and to form a virtuous circle of mutual promotion. American economist Raymond W. Goldsmith in "Financial Structure and Financial Development" (1969) summarized the long term multinational financial development data, obtained the regular conclusions, and put forward an important quantitative analysis index of "Financial Interrelations Ratio" (FIR). Goldsmith thought that "it is defined as the ratio of all financial assets value and real assets (i.e. national wealth), which is to measure the generalized index in financial superstructure with relative scale." Through the calculation of the financial interrelations ratio, the lower financial interrelations ratio shows that the financial system is in a low stage of development, between 0.2 and 0.5; while the higher financial interrelations ratio is about 1 , may be with certain fluctuations, which shows that the diversification of financial institutions and services in the financial system is more common in the developed countries.

\section{Current Situation of County Financial Development in Shaanxi Province}

Analysis of County Economic Aggregate . Through the data it can be seen from 2009 to 2013 years, the growth rate of Shaanxi's gross production is basically the same as the growth rate of GDP, which is higher than the national average. In the big environment of the national economic downturn and insufficient macro demand, maintaining a high growth rate has made Shaanxi step in the first echelon of national economic development. Among the ten strongest counties of Shaanxi Province such as Gaoling County, Jingbian County, and Zhidan County, Gaoling County has the highest growth rate of gross production and holds a safe lead; the average growth rate of Jingbian County and Zhidan County is relatively close to the average growth rate of Shaanxi Province. It can be clearly seen in 2011, economic growth was turned from high speed to mid high speed. In the face of the economic downturn in the world market, there is a serious shortage of foreign demand. At the same time, there is a long-term accumulated structural factor, resulting in the slowdown in economic growth. From the nation to provincial cities and to counties, all are faced with the major issue of the adjustment of economic structure.

County Financial Structure Analysis. From the data, individual savings deposits of the three counties remain a stable growth, which is still the main source of RMB deposits. Broken line of loan-to-deposit ratio of the three counties was made after the calculation of deposit data of the three counties, in which the values of deposit and loan of Gaoling County maintains a relatively high growth, but with a relatively low ratio of savings and loan; loan-to-deposit ratio of Zhidan County is in the medium level; loan-to-deposit ratio of Jingbian County is relatively high, with a breakthrough in the proportion of commercial bank loans and deposits not to exceed 75 percent of the loan-to-deposit ratio limitation. Deposit and loan data changes reflect some of the current economic operation of the three counties: there is a stable increase in personal income and savings deposits remain stable growth. Lower loan-to-deposit ratio means lower funds use rate and the return rate on assets, showing that in the county economic development, financial support is insufficient, the funds are not invested enough, credit and security system needs to be further improved. Low ratio of loan and deposit has become the bottleneck of the development of county finance. Higher loan-to- deposit 
ratio indicates the strong investment in the real economy to a certain extent, but needs to pay attention to risk control, liquidity pressures and non-performing loan rate.

Analysis of County Population Urbanization. Premier Li Keqiang stressed in talking of the economic and social development that urbanization is the trend of economic and social development; the largest domestic demand for expanding domestic demand lies in urbanization and the strongest domestic demand is in urbanization, so this stage should be based on urbanization, adjust and optimize the urban and rural areas and regional structure, to expand consumer demand and investment demand, and to promote long-term stable and rapid economic development. The finance has positive support function to the urbanization advancement; therefore, take the urbanization rate index into account when evaluating the county financial development. In the calculation of urbanization rate, according to the provisions of National Bureau of Statistics, the rate of urbanization $=$ urban population / total population (calculated with the resident population). With the calculation method of urbanization rate $=$ urban population / resident population, population urbanization rate can be as an index to measure county urbanization. From 2009 to 2013, the national average rate of urbanization is from $48.34 \%$ to $53.73 \%$. It can be seen from statistical data that the three counties of Shaanxi has higher level of urbanization than the national average. Rapid advance of urbanization can stimulate investment, promote consumption, and increase employment. Urbanization and financial development are complementary to each other; along with the need for urban construction and functional improvement, there is a huge demand for financial services, which also has been actively promoting sound financial system, channel development, and structural optimization. China's future new urbanization will generate a great money demand. I believe that the future capital needs for the new urbanization are mainly reflected in the four aspects such as construction of urban public utilities, urban real estate development, small and micro enterprises and urban resident consumption.

Analysis on Financial Interest Rate. In the empirical analysis part, it will take the real interest rate as the measure index for the county financial development, and take the county GDP growth as the measure index for the county economic development, and establish the analytical model.

Analysis on Financial Interrelations Ratio. From the statistical data it can be seen, the overall financial interrelations ratio of Shaanxi province and the three counties are relatively stable without large fluctuation, showing that there is the macro financial policy that makes the changes in financial assets stable. Among them, the difference of the financial interrelations ratio of the three counties of Gaoling County, Jingbian County and Zhidan County is very obvious compared with that of Shaanxi Province. In the three counties, financial interrelations ratio of Gaoling County is in a leading position, Jingbian County is slightly backward, and Zhidan County has the lowest financial interrelations ratio, indicating the financial development speed and level to be improved.

\section{Empirical Analysis of County Finance in Shaanxi Province}

Establishment of Index System. In order to reflect the supporting role of related financial services in the development of county economy, we select GDP increment (Y) of the three counties of Gaoling County, Jingbian County, Zhidan County as explained variable, loan-to-deposit ratio (X2), population urbanization rate $(\mathrm{X} 3)$ and actual loan rate (X4) as explanatory variables.

The set linear regression model is:

$\mathrm{Y}=\beta 1+\beta 2 \mathrm{X} 2+\beta 3 \mathrm{X} 3+\beta 4 \mathrm{X} 4+\mathrm{u}$ 
Analysis Method Selection and Data Processing.

\begin{tabular}{lrlll}
\multicolumn{5}{c}{ Figure 1 Data Processing Results of Gaoling County } \\
\hline \hline \multicolumn{1}{c}{ Variable } & Coefficient & Std. Error & t-Statistic & Prob. \\
\hline \hline C & -59.90844 & 21.53244 & -2.782241 & 0.0689 \\
\multicolumn{1}{c}{ X2 } & 421.1506 & 92.76493 & 4.539977 & 0.0200 \\
\hline \hline R-squared & 0.872943 & Mean dependent var & 37.47000 \\
Adjusted R-squared & 0.830590 & S.D. dependent var & 10.28187 \\
S.E. of regression & 4.231960 & Akaike info criterion & 6.012382 \\
Sum squared resid & 53.72846 & Schwarz criterion & 5.856157 \\
Log likelihood & -13.03095 & Hannan-Quinn criter. & 5.593090 \\
F-statistic & 20.61139 & Durbin-Watson stat & 1.314306 \\
Prob(F-statistic) & 0.020009 & & \\
\hline \hline
\end{tabular}

\begin{tabular}{lrlll}
\multicolumn{5}{c}{ Figure 2 Data Processing Results of Jingbian County } \\
\hline \hline \multicolumn{1}{c}{ Variable } & Coefficient & Std. Error & t-Statistic & Prob. \\
\hline \hline C & 60.33343 & 4.807747 & 12.54921 & 0.0011 \\
\multicolumn{1}{c}{ X4 } & -1052.976 & 157.8360 & -6.671332 & 0.0069 \\
\hline \hline R-squared & 0.936851 & Mean dependent var & 31.52400 \\
Adjusted R-squared & 0.915801 & S.D. dependent var & 16.28500 \\
S.E. of regression & 4.725420 & Akaike info criterion & 6.232964 \\
Sum squared resid & 66.98879 & Schwarz criterion & 6.076740 \\
Log likelihood & -13.58241 & Hannan-Quinn criter. & 5.813672 \\
F-statistic & 44.50667 & Durbin-Watson stat & 2.009092 \\
Prob(F-statistic) & 0.006867 & & & \\
\hline \hline
\end{tabular}

Statistical Analysis. Due to the limited data, coupled with the 2008 U.S. subprime mortgage crisis outbreak, resulting in a number of large financial institutions closing down or taken over by governments, the further development of the financial crisis has evolved into a global economic crisis, so that the county economic development of Gaoling County, Jingbian County and Zhidan has been facing a serious problem in the years from 2009 to 2013 influenced by the overall downward of global and domestic economy. In this special period, the government has adopted a positive macroeconomic policy to adjust the county economic and financial development for the national economic development to maintain stability.

\section{County Financial Development Strategy in Shaanxi Province}

Establish and Improve the County Financial System. In the county economy development, the sound and effective county financial system is the key power to promote the long-term sustainable growth of county economy. Therefore, where the financial system is more developed, the capital market is more developed in the region, and the real economy is more fully developed. To establish and improve the county financial system in Shaanxi, the first job is financial infrastructure construction, to enhance the coverage and depth of financial services, to schedule and integrate financial resources, and to solve the shortage of financial service network and conditions.

Encourage Private Finance; Strengthen Market Competition. Reduce the access threshold for the county financial markets, relax the banking industry access policies, allow financial capital, industrial capital, private capital and other social capitals to participate in the county financial markets, and strongly support the construction of private banks, small and medium banks and non-bank financial institutions. At this stage, there are some areas of development lacking of sufficient financial resources and supports, so to encourage the private finance and market competition is conducive to the development of the market and improvement of the capital use efficiency, which will effectively compensate for the lack of large financial institutions in the field of service. At the same time, reduce barriers to entry, enhance the regulatory efforts and effectively control the risk, and establish an effective private financial capital constraint mechanism.

Promote the Market Reform of Interest Rate. Further promotion of the market reform of the interest rate has an important positive effect on the county financial environment, which can effectively reduce the phenomenon of financial repression. By financial institution's reasonable pricing to financial products, the finance is made to further support the development of county real economy and to improve the efficiency of the use of funds. The market pricing has also promoted the optimization and upgrading of economic structure. Interest rate marketization is conducive to the absorption of a wide range of regional deposits and to attract idle funds, to play a role of funding, to accelerate the flow of funds and to promote economic development.

Promote Innovation of County Financial Product. Diversification of County financial product innovation and services can effectively reduce the idle and outflow of funds. Meet the needs of the county's financial development by encouraging product innovation, and expand the scope of financial services. Through the statistical data, it can be seen that loan-to-deposit ratio of sample in Gaoling County is at the lower level; through regression analysis improve positive correlation of 
loan-to-deposit ratio with the increment of GDP. Therefore, explore the variety of credit products and change the traditional consumption habits, so as to make the capital meet the demand of different levels and areas. Through the establishment of incentive system, encourage innovation and establish the concept of innovation, to improve the enthusiasm of county financial product innovation.

Develop County Finance According to Local Conditions. County finance should be combined with local features to service local development. According to the differences of county economy development levels, related policies and system, county population structure, the degree of urbanization and market degrees, rely on business characteristics and the actual conditions of social development, reasonably determine the development objectives and strategy, and follow the development path of "specialization", to constantly enhance the competitive power. Through in-depth research and analysis of the market, grasp the market demand and regional characteristics, combined with the county policy direction, to play an active role in the local economic and social development of financial services.

County Finance and Urbanization. In 2015, Premier Li Keqiang in the government work report said that urbanization is the fundamental way to solve the problem of gap between urban and rural areas, which is also the largest domestic demand. At present, the urbanization rates of our country and in Shaanxi Province are lower than that of the developed countries, and there is still a huge space to rise. Urbanization and county financial development have a complementary relationship between the two. Along with the process of urbanization, huge investment demand will drive the rapid and multidirectional development of county finance; while the county finance urbanization will further focus on capital, population, education, medical and other resources, to promote the further development of urbanization for the formation of a virtuous circle of mutual promotion and mutual progress, and the release of dividends in the process of urbanization.

Improve External Environment of County Finance.Accelerate the construction of the county credit system, promote credit rating system, establish and improve the corporate and personal credit files to bring into the national credit system, improve the cost of credit default, and increase the intensity of sanctions, to train good credit consciousness. Accelerate the government decentralization, and reduce excessive intervention of financial institutions, through legal means to protect the financial agency bonds and to maintain financial order in the county. Through a variety of channels to carry out the popularity of financial literacy, improve the popularity and use of financial innovation products.

\section{References}

[1]Burhop C. Did Banks Cause the German Industrialization [J]. Explorations in Economic History.2006, 43(1)

[2]Levine, Ross.Bank-based or Market-based financial systems:which is better[M].University of Minnesota, 2000

[3]Beck T, Kunt AD, Levine R. SMEs, Growth and Poverty:Cross-County Evidence [J]. Tournal of Economic Growth, 2005(10):199-229.

[4]Pal,Sarmistha(2002). Household sect oral choice and effective demand for rural credit in India. Applied 36Economics,2002( 14): 1743 1755.

[5]Pham, Bao D.,\&Yoichi Izumida. Rural Development Finance in Vietnam:A .(2002) Microeconometric Analysis of Household Surveys. World Development 30(2):319 335 .

[6]Schoombee GA, S van der Berg, FN Okurut Credit demand and credit rationing in the informal financial sector in Uganda. South African Journal of Economics, (2004). 73(3)

[7]Siamwalla,A, The Thai rural credit system: Public subsidies, private Information ,and segmented markets. World Bank Economic Review(1990). 4(3):271 295

[8]Wenner. Managing credit risk in rural financial institutions:what seems to work [J]. Enterprise development and microfinance.2007(9): 158 174. 